CORRECTION

\title{
Correction: Microbial niche differentiation explains nitrite oxidation in marine oxygen minimum zones
}

Xin Sun (D), Claudia Frey, Emilio Garcia-Robledo, Amal Jayakumar (iD) and Bess B. Ward (D)

The ISME Journal (2021) 15:2492; https://doi.org/10.1038/s41396-021-01032-7

Correction to: The ISME Journal https://doi.org/10.1038/s41396020-00852-3, published online 06 January 2021

After publication of this article, the authors realized that proteins encoded by the OMZ NOB MAGs were incorrectly annotated as chlorite dismutase $(\mathrm{Cld})$. They are homologs of $\mathrm{Cld}$, and they should be called Cld-like proteins. Key residues for $\mathrm{Cld}$ are missing in these proteins and their chlorite dismutation activity is not expected. Thus, we correct 'Cld' into 'Cld-like proteins' for OMZ NOB MAGs.

The authors acknowledge Dr. Tyler Barnum for pointing out this issue.

The original article has been corrected. (c) (i) Open Access This article is licensed under a Creative Commons C. Attribution 4.0 International License, which permits use, sharing, adaptation, distribution and reproduction in any medium or format, as long as you give appropriate credit to the original author(s) and the source, provide a link to the Creative Commons license, and indicate if changes were made. The images or other third party material in this article are included in the article's Creative Commons license, unless indicated otherwise in a credit line to the material. If material is not included in the article's Creative Commons license and your intended use is not permitted by statutory regulation or exceeds the permitted use, you will need to obtain permission directly from the copyright holder. To view a copy of this license, visit http://creativecommons. org/licenses/by/4.0/.

(c) The Author(s) 2021 